\section{Evaluation of Pinyon-Juniper Conversion to Grassland ${ }^{1}$}

\section{RICHARD S. ARO²}

Botanist, Water Resources Division, U.S. Geological Survey, Denver, Colorado.

\section{Highlight}

Conversion techniques applied to public lands in Colorado, Utah, Arizona, and New Mexico provided the

${ }^{1}$ Publication authorized by the Director, U.S. Geological Survey. Received October 22, 1968; accepted for publication January 11, 1971.

2 Present address is Department of Range Science, Colorado State University, Fort Collins, Colorado 80521. basis for an evaluation of several methods. Burning was the most effective and the least expensive method studied. Dozing of trees into windrows, followed by seeding of grasses in the cleared areas, was the best mechanical approach examined, but requires careful site selection and economic evaluation. Chaining was the most widely used, but the least effective technique for converting pinyonjuniper woodland to grassland.
Livestock grazing is the major use of the pinyon-juniper vegetation typc. In many areas it provides critical spring and fall range for large numbers of cattle and sheep. Heavy grazing of pinyonjuniper ranges has not only caused a decline in forage production, but has been accompanied by increases in density and extent of tree stands. Invasion of grasslands by juniper trees and the thickening of established pinyon-juniper stands have been associated with the removal of grass competition by grazing (Nichol, 1943; Woodbury, 1947; Arnold, 1959; Mason, 1963), and also with the reduction of woodland fires (Leopold, 1924; Pearson, 
1931; Parker, 1945; Arnold and Schroeder, 1955; Humphrey, 1962; Johnsen, 1962; Choate, 1966).

Owners and managers of pinyonjuniper rangelands seek ways to control these unwanted trees and convert woodlands to grasslands to increase forage production. Public agencies, in particular, are also interested in the improvement of wildlife habitat, increased water yields, and reduction of sediment yields in many parts of the pinyonjuniper region.

A number of methods have been used to control pinyon and juniper trees to improve range production and watershed conditions. The objectives of this study were: (l) to evaluate techniques used to convert pinyon-juniper woodland to grassland, and (2) to define the site conditions under which certain conversion methods should yield the best results.

The author gratefully acknowledges the help of Farrel A. Branson and Lynn M. Shown, Water Resources Division, U.S. Geological Survey, Denver, Colorado; the late William L. Schroeder, Bureau of Indian Affairs, Valentine, Arizona; R. R. Humphrey, Tucson, Arizona; and personnel of the Bureau of Land Mandagement districts where conversion practices were evaluated.

\section{Description of the Pinyon-Juniper Type ${ }^{3}$}

The pinyon-juniper woodland type covers about 65 million acres located largely in Arizona, Colorado, Nevada, New Mexico, and Utah (U.S. Dep. Agr., 1958). It varies from nearly closed stands of single tree species with almost no understory vegetation to wideopen stands of pinyon, juniper, or both, scattered among grasses and shrubs. A typical pinyon-juniper woodland has the aspect of a stunted coniferous forest, with its many-branched trees often appearing more like shrubs. Pinyon and juniper trees are seldom more than

${ }^{3}$ For more detailed descriptions of the pinyon-juniper type see Dortignac (1960) and Arnold et al. (1964).
40 feet tall and are usually shorter than 20 feet, while trunk diameters rarely exceed 24 inches (Preston, 1940). A pinyon-juniper stand usually does not contain a large number of different plant species, but because of the wide distribution of the type, the total associated flora includes a rich variety of woody and herbaceous plants.

Pinyon (Pinus edulis) and either Utah juniper (Juniperus osteosperma) and one-seed juniper ( $J$. monosperma) are the only important tree species in the community through most of its range. Utah juniper is the usual codominant with pinyon in Nevada, Utah, western Colorado and northwestern Arizona. One-seed juniper normally occurs with pinyon from northcentral Arizona through New Mexico and into Texas and parts of southern Colorado. However, since Utah juniper and one-seed juniper are so similar, both taxonomically and ecologically, the distinctions between them will be ignored, and hereinafter "juniper" will refer to either or both of these species. In Nevada, and at some localities in western Utah and northwestern Arizona, singleleaf pinyon $(P$. monophylla) is the codominant with one of the junipers, and also frequently occurs in nearly pure stands. Rocky Mountain juniper (J. scopulorum) is found over most of the range of pinyon-juniper woodlands, usually at the upper altitudinal levels, but seldom as a dominant in the mixed community.

Shrubs and half-shrubs which are commonly present with pinyonjuniper stands include: mountain-mahogany (Cercocarpus sp.), antelope bitterbrush (Purshia tridentata), serviceberry (Amelanchier sp.), big sagebrush (Artemisia tridentata), black sagebrush (A. nova), rabbitbrush (Chrysothamnus sp.), cliffrose (Cowania mexicana), Apache-plume (Fallugia paradoxa), jointfir (Ephedra sp.), oak (Quercus sp.), yucca (Yucca sp.), pricklypear (Opuntia sp.), snakeweed (Gutierrezia sarothrae), and eriogonum (Eriogonum sp.).
Grasses common to the pinyonjuniper type are: Indian ricegrass (Oryzopsis hymenoides), needleandthread (Stipa comata), squirreltail (Sitanion hystrix), junegrass (Koeleria cristata), galleta (Hilaria jamesii), blue grama (Bouteloua gracilis), side-oats grama (B. curtipendula), ringgrass (Muhlenbergia torreyi), western wheatgrass (Agropyron smithii), bluebunch wheatgrass ( $A$. spicatum), slender wheatgrass (A. trachycaulum), downy chess (Bromus tectorum), and threeawn (Aristida sp.).

Most of the pinyon-juniper woodland lies between 5,000 and 7,000 feet altitude and receives 10 to 14 inches of precipitation annually. Pinyon-juniper woodlands occur on a wide variety of underlying rocks including sandstone, limestone, basalt, and the soils derived from them. According to Woodbury (1947), the upper limits of the zone in Utah and northeastern Arizona vary from 6,500 feet on north-facing slopes on the Kaibab Plateau to about 8,400 feet on south-facing slopes of the Book Cliffs in eastcentral Utah. He gave 5,200 feet as the typical lower limit for pinyonjuniper in the Great Basin and Colorado Basin, with a possible extreme low for the type in that region at 3,200 feet near St. George, Utah. Johnsen (1962) reported that one-seed juniper "may be found growing from about 3,000 feet in the upper parts of the deserts to above 7,500 feet in the ponderosa pine forests." Outliers of one-seed juniper occur down to 3,000 feet along the southeastern limits of the coniferous woodland in Texas. Pinyon pine is found up to an altitude of about 9,000 feet on the west side of Trout Creek Pass in Colorado.

\section{Evaluation of Conversion Practices}

The evaluation of conversion methods was aimed at the two main objectives of such treatments, kill of trees and production of grass forage. Techniques for killing pinyon or juniper trees fit under 
three general headings: mechanical means, chemical means, and fire. Mechanical methods and fire effects were included in the present study. Chemical controls are relatively new in pinyon-juniper management and were not evaluated.

Mechanical treatments that were studied included single chaining, double chaining, and chaining followed by windrowing. Chaining, the most widely used method, involves attaching the ends of heavy anchor chain to a pair of crawler tractors, which then drag the loop of chain through the trees. Weight of the chain varies from about 45 to 90 pounds per link, and lengths range from about 250 to 600 feet. Double chaining is the same process, repeated in the opposite direction. The purpose of chaining is to knock down or rip out the trees and provide some scratching of the soil surface for coverage of grass seed. Windrowing is the scraping of downed trees, with some soil, into long ridges, or windrows, which leaves cleared ground over most of the treatment area. This method normally includes drilling of adapted grass species.

Fire can be placed in two technical roles in pinyon-juniper conversion. First, there are the socalled wild, or accidental fires which are a natural phenomenon of pinyon-juniper woodlands. The other kind of fire has similar effects, but is directly and intentionally caused by man in an effort to eliminate trees. Either type may fizzle in short time and burn very little or may sweep over a large area. The size depends on a number of factors such as weather, vegetation, fire breaks, and the wishes of watchers.

All of these techniques kill trees. How they differ in application, effectiveness and cost is what interests land managers and provides the framework for this evaluation.

Bureau of Land Management district offices in Colorado, Utah, Arizona and New Mexico were asked to submit completed landtreatment reports for any pinyon-

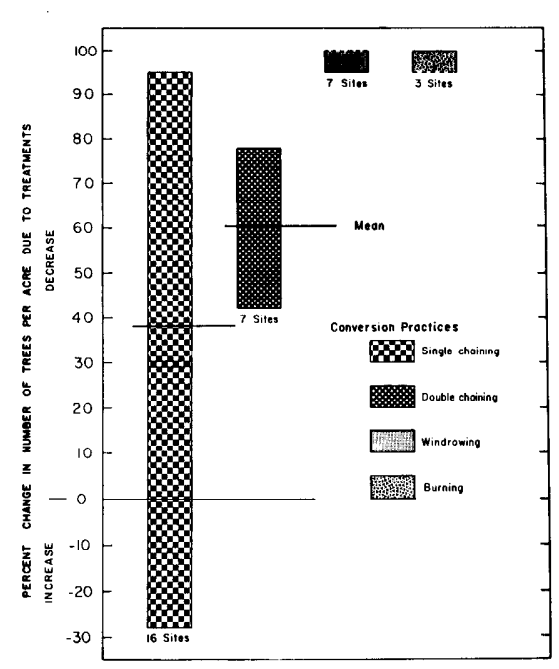

Fig. 1. Variations in trec kill for different conversion practices. Percent change in number of trees per acre due to treatment is the ratio of the number of live trees per acre on a treated site to the number of live trees on an adjacent untreated site. Height and position of bar indicates range and degree of success for control method.

juniper projects that were completed prior to June 1963. Out of the 113 land-treatment reports received, about 50 sites were selected for examination during the summer and fall of 1964. Those selected gave a wide geographical range to the study and were representative of the group of projects reported by the Bureau of Land Management districts.

Tree species, numbers, and height classes were sampled in one-fifth acre plots on treated and adjacent untreated sites. Surface soil to 30 centimeters was sampled and analyzed for physical and chemical properties that might affect grass production. Yields of forage grasses on treated and untreated areas were estimated on a dry weight basis in pounds per acre.

\section{Results and Discussion}

Most of the sampling sites had received single chaining; next in number were double chaining areas; the third group represented the intensive chaining and windrowing technique. The study included three sites where fire had removed the tree competition.
Tree density on untreated sites ranged from 85 to 710 trees per acre for pinyon and juniper combined, with an average of 340 trecs per acre. Untreated sites had an average of 180 pinyon trees and 160 juniper trees per acre.

Figure I compares tree control efficacy of conversion practices. Average kill for single chaining was 38 percent and for double chaining, 60 percent. Estimates of kill for windrowing and burning ranged from 95 percent to 100 percent. Dashed lines are used on the graph bars for windrowing and burning to indicate that some windrowing treatments may not have killed 100 percent of the trees, and that tree kill may not have been so low as 95 percent for any of the burns. Two of the single chaining sites had more trees per acre on the trcated area than on the untreated area, which accounts for the single chaining bar extending below zero kill.

Forage production was consistcntly low in untreated woodlands, but varied greatly on treated sites. Some of the single-chaining areas showed little or no change in forage yield, but the average increase for the group was about 100 percent. However, the actual amounts of forage involved on chaining projects were generally so low that the poor tree kills overshadowed any gains in grass production. One notable exception was a singlechaining project in northwestern Colorado which had a tree kill of about 95 percent and a boost in grass forage from about 100 pounds per acre before treatment to $\mathbf{5 0 0}$ pounds per acre after treatment. Yields of grass from windrowed sites ranged from 500 to over 1,000 pounds per acre.

Recovery of grasses on the burned sites was dramatic. Forage production of desirable native grasses was 1,300 pounds per acre on one wildfire site and only about 100 pounds per acre in the adjacent unburned woodland. At the other two fire sites examined, the pounds of forage per acre increased from an estimated 200 to over 600 , at one 
site, and from 25 to almost 500 pounds per acre at the other.

Conversion of woodland to grassland must accomplish two functions almost simultaneously to be complete and successful. These are (1) removal or drastic reduction of tree growth and (2) replacement of trees by grass as the dominant vegetation of the site. A complete kill of trees without establishment or equivalent release of a grass cover is not conversion of woodland to grassland; nor is an increase in grass production through means that kill some trees but leave most of them alive and reproductive. Arbitrary, quantitative levels for "success" and "failure" of pinyon-juniper conversion treatments suffer both from the vagaries of management goals and the fallibility of ecologic criteria. Vegetation manipulation is more an art than a science and appraisal of its results must necessarily be rather subjective. Nonetheless, pinyon-juniper conversion practices should be compared in terms of tree kill and grass establishment, since ostensibly these are the main objectives of such treatments. Other results of pinyonjuniper control which may be desirable, such as the release of browse plants for wildlife, will require different evaluation criteria (Plummer et al., 1968).

\section{Chaining}

Based on the criteria of killing trees and producing forage, there was only one successful chaining site among the many examined. Another project in Utah achieved a successful conversion with double chaining augmented by burning. The almost universal failure of chaining, without windrowing, to kill a high enough percentage of trees is the single most discouraging aspect of pinyon-juniper conversion efforts.

Chaining often kills a majority of the older, larger trees in a stand, but usually leaves most of the young trees without damaging them seriously or preventing them from producing seed.
Cotner (1963) found cabling to be "particularly adapted for evenaged stands" of pinyon-juniper, but also noted that, "in a mixed-age stand, the cable is lifted off the ground while the larger trees are pulled, thus missing smaller trees which bend and are passed." $\mathrm{He}$ reported that, "cabling pulled 94 percent of the trees in an even-age stand of trees, 15 to 25 leet in height, on a shallow limestone site. In contrast, on a clay site, the count of dead trees was only 43 percent in a mixed-age stand on which originally better than half of the trees were seedling size to six feet." Arnold et al. (1964) concluded that, "Cabling or chaining is probably the best method for uprooting dense stands of old pinyon-juniper trees," but observed that "the cable slips over small trees (10 feet high and smaller) and merely tips over many intermediate-sized trees." This normally killed the larger trees and left the smaller ones alive. According to Chilson, the smaller trees that survived had a post-treatment acceleration in growth, which meant that he was faced with "much the same problem of over supply of pinyon-juniper that was present before the initial cabling." Plummer et al. (1968) observed that cabling was "less effective than chaining for eliminating young, flexible juniper and pinyon trees."

Data from the present study also show a relationship between size of trees and effectiveness of chaining. Among a group of five sampling sites, where the percentage of trees greater than 10 feet in height made up 50 percent or more of the stand, single chaining killed from 46 to 84 percent of all trees. The kill average 61 percent in these older stands, or approximately the degree of control obtained with double chaining. By comparison, single chaining killed an average of only 30 percent of all trees on projects where over one-half of the trees on the untreated sites were less than 10 feet in height. These results suggest that the probability of successful pinyon-juniper kills from chaining will increase in direct relationship to the percentage of trees 10 feet tall and taller that are present in the untreated woodland. According to personnel in one Bureau of Land Management district, chaining may work better in mid-winter when the soil is frozen. Under these conditions a good kill was obtained on a mixed age stand in northeastern Utah. Recent innovations have increased the effectiveness of anchor chaining. One such development is the "Ely Chain," a 90-pound per link chain with 40-pound railroad iron welded across each link. Treatments with the "Ely Chain" in eastern Nevada have demonstrated its value in controlling all age classes of pinyon and juniper (Gain, 1969).

Many chained areas enjoy a flush of increased grass production soon after treatment, but regrowth and release of young trees cancels out the early forage gains. Small trees that are missed by cabling or chaining "grow two to three times as fast after release from the dominance of larger overstory trees", (Arnold et al., 1964). The young trees present a formidable challenge to follow-up control, unless effective chemical controls are developed, and even if prescribed burning were allowed, the nature of some post-treatment stands precludes anything else but additional mechanical treatment. Inexpensive chaining, which may kill a relatively high percentage of old trees while leaving most of the young ones and releasing seedlings, can create an ecologic situation that is harder and more expensive to treat than the original woodland. Trees that remain could be cut down individually by hand or perhaps even burned, one by one. But these methods might be prohibitive in cost, depending on the degree of original conversion success and the forage potential for the site. Figure 2 illustrates the problem of reestablishment of trees on a chained area. Six years after treatment the site had 275 live trees per acre, as compared with 215 on an adjacent 


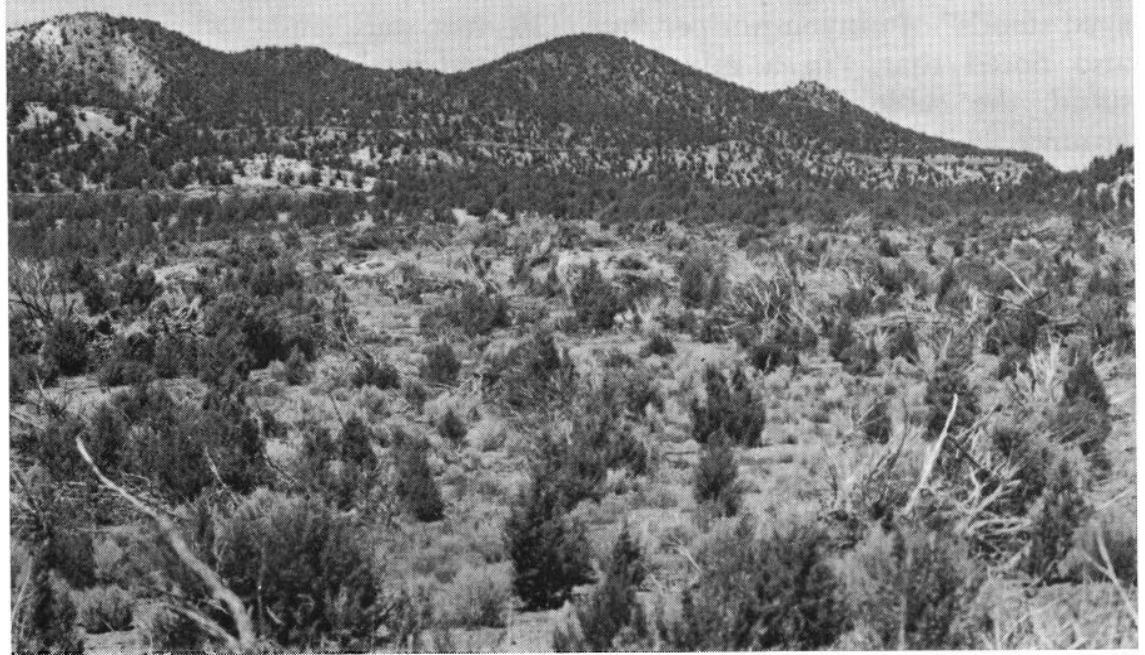

FIG. 2. Chained woodland, northwestern Arizona, 6 years after treatment. Most of the live trees are junipers less than 5 feet tall.

untreated area. Ninety-five percent of the trees on both areas were juniper. All of the trees sampled on the treated site were less than 10 feet tall, and two-thirds of them were less than 5 feet tall. In the adjacent untreated stand two-thirds of the juniper trees were taller than 10 feet.

A major weakness of the chaining approach seems to lie with a misplaced emphasis on saving money rather than producing benefits. The object of a pinyon-juniper conversion is, by definition, to get rid of trees in a given area and replace them with grass. Any practice which does not accomplish these aims with ecologic and economic efficiency is a failure as pinyonjuniper conversion, no matter how inexpensive it may seem to be. If different primary objectives for pinyon-juniper control are adopted, such as improvement of wildlife habitat, then the above criteria for success and failure may not apply. In any case, it is unreasonable to assign broader meanings to these conversion standards than those intended in the present context.

\section{Windrowing}

Compared to chaining operations, the intensive chaining-windrowing-drilling technique, though more costly, is a far better mechanical means of replacing trees with grass. Clearing the ground completely, which is necessary for drilling, not only provides a clean kill of trees and a control on shrubs, but the resulting stands of grass surrounded by untreated woodland probably have as much aesthetic value to residents and travelers as does the typical pinyon-juniper scenery. The method is also ecologically sound. Grass establishment is more dependable and tree reinvasion is less of a problem where clean scraping and drilling are practiced. The windrowing site shown in Figure 3 typifies the outstanding pinyon-juniper conversions accomplished by Bureau of Land Management personnel in southwestern Utah.

Since the windrowing technique is essentially a form of dryland


FIG. 3. Juniper-pinyon woodland, southwestern Utah. Left: Untreated site with 315 trees per acre, of which about 90 percent were juniper. Sixty percent of the junipers were less than 10 feet in height. Understory shrubs were big sagebrush, snakeweed, and rabbitbrush. Forage production was negligible. Right: Adjacent windrowed site was typical of windrowing conversions examined. Treatment killed 95 percent or more of the trees, reduced shrub cover, and increased annual forage production to over 500 pounds per acre. 
grass farming, its success largely depends on soil and climatic factors. Choice of location and risk of drought are the main problems. Site requirements outlined by Cook (1966) for seeding of foothill ranges in Utah should be applicable to much of the pinyon-juniper type. He suggested that "annual precipitation should be at least 11 inches and preferably 13 to 14 inches if optimum returns are to be obtained." Cook's studies also indicated that the soil depth on seeding sites should be about 24 inches or more for full development of grass roots and to utilize expected annual precipitation. Shown et al. (1969) presented data from crested wheatgrass seedings in the sagebrush type which suggested that the average limit of rooting depth for herbaceous species was about 2 inches for each inch of average annual precipitation in the 11- to 14-inch precipitation zone. The latter study also showed that the highest yields of crested wheatgrass occurred on sites with sandy loams, loams, or silt loams at the surface, and finer textured subsoils. These soils were reported to give an optimum balance between the properties of moisture infiltration, moisture-holding capacity, and moisture availability to plants. Surface soils on the windrowing sites examined in the present study classified as sandy loam, silt loam, or sandy clay loam.

Drilling of seed is preferred to broadcast seeding for establishment of grass in dry regions (Cook, 1966; Hull et al., 1952; Shown et al., 1969; Stoddart and Smith, 1955), but drilling requires sites that are relatively free of rocks and woody vegetation. Wilson et al. (1970), reported that seeds of crested wheatgrass planted at a depth of 1 inch germinated well because of relatively constant and favorable moisture conditions whereas seeds on the soil surface failed to germinate because of generally unfavorable and rapidly fluctuating moisture conditions. Soilmoisture conditions were shown to have a critical effect on certain metabolic processes essential to germination.

Thus, drilling can reduce the risk of a seeding failure by mitigating climatic stress during germination and cstablishment, but soil requirements limit the windrowing technique to certain areas. The following criteria are suggested for selection of windrowing sites:

(1) Soil Deplh-Minimum soil depth should be 24 inches.

(2) Soil Texture-Surface soil should be a sandy loam, silt loam, or silt.

(3) Stoniness-Soil should be sufficiently free of rocks to allow drilling of grass seed.

(4) Slope-Slopes should not exceed 15 percent.

There is an interesting and important connection between windrowing conversions and wildlife habitat. First, in order to use the windrowing technique intelligently and successfully, the land manager must make a thorough survey of site conditions in the proposed treatment locality. Selection of sites to treat should recognize certain basic ecologic criteria such as slope and stoniness of soil, as discussed earlier. By careful delineation of treatment areas, leaving out those woodlands that are too steep or too rocky for conversion to grassland, the manager will, in effect, be classifying the land resources into "natural" and "modified" areas. The untreated woodland sites will continue to provide the kind of habitat conditions that wildlife conservationists desire, whereas the adjacent converted areas will produce needed forage, primarily for livestock, but not entirely avoided by deer.

In a report on game habitat use in southern New Mexico, Reynolds (1964) stated that livestock range improvement can be coordinated with deer and elk habitat preservation by confining clearing of pinyon-juniper to slopes of less than 15 percent, and leaving existing cover on northeastern exposures. Reynolds felt that elk and deer habitat might be improved by thinning trees, which overtop shrubs, where they exceed about 150 trees per acre.

A windrowing conversion program is essentially self-classifying, from a land-use standpoint, since ecologic criteria restrict the practice to certain sites which will usually produce greater benefits when converted to grassland than if left untreated. Stony, wooded ridges and canyon slopes scattered among grass-covered valleys and mesa tops is the sort of vegetation pattern that will normally result from this conversion technique. Soils that are better suited to tree and browse production generally are not included with windrowing and drilling sites. Whenever large areas selected for windrowing do not contain enough stony, steep, or otherwise naturally unsuitable conversion sites to satisfy a legitimate necd for wildlife food and cover, the necessary islands of untreated woodland can easily be left anywhere in the project. It is simply a matter of the land manager being sensitive to the desires for a balanced vegetation modification program and his being willing to refine the planning and execution of the conversion to accomodate a companion resource.

The same reasoning could apply to the coordination of any conversion practice with other land values in the pinyon-juniper type, such as camping and picnicing needs, historical and archeological sites, areas of particular scenic or scientific interest, or any other feature of a woodland that should receive special attention.

\section{Burning}

Fire can be an effective tool in the conversion of pinyon-juniper woodlands to grasslands. Clean kills of trees and certain understory shrub species, notably big sagebrush, can be achieved with fire on a large part of the woodland type. Although only a few burned sites were reported by Bureau of Land Management district offices for in- 
clusion in this study, the rather obvious success of those examined permits some latitude in attributing general usefulness to fire. Burning does not allow the high degree of site selection and treatment control that windrowing does, but may have greater merit for improving combined livestock-wildlife range than would be imagined. For example, Arnold et al. (1964) observed from aerial views of pinyon-juniper burns that while tree kill often was "clean on flat to gently rolling terrain ... in rough terrain, islands of unburned trees were left on hills and ridges." Preferred deer browse species that resprout after a fire, such as birchleaf mountainmahogany (Gercocarpus betuloides) and Wright silktassel (Garrya wrightii), may provide additional incentive in some areas to remove tree competition with a controlled burning program (U.S. Dep. Agr., 1963). Other valuable browse species that tolerate fire include: antelope bitterbrush, desert bitterbrush (Purshia glandulosa), Apache-plume, Saskatoon serviceberry (Amelanchier alnifolia), blueberry elder (Sambacus cerulea), black chokecherry (Prunus virginiana) and Rocky Mountain smooth sumac (Rhus glabra cismontana) (Plummer et al., 1968).

A program of planned burning on the Hualapai Indian Reservation in northern Arizona has demonstrated the effectiveness of this technique in pinyon-juniper conversion. Schroeder (1961) reported on a wildfire that burned off 16,000 acres of pinyon-juniper woodland on the reservation in 1953 . The burn was seeded to the following mixture in 1954: crested wheatgrass, 1 pound per acre; western wheatgrass, 3 pounds per acre; weeping lovegrass, $1 / 2$ pound per acre; and yellow sweet clover, 1 pound per acre. Grazing was deferred for 3 years following seeding to allow the grasses to become fully established. Cost of the project was $\$ 3.60$ per acre. Dry weight of forage in adjacent unburned areas avcraged about 60 pounds pcr acre, while production on the seeded burn was 1,660 pounds per acre.

Encouraged by the beneficial results from an accidental fire and followup seeding, and aided by their government advisors and technicians, the Hualapai Indians launched a controlled burning program to convert pinyon-juniper woodland to produclive grassland. In the period from 1955 through 1963 they burned and seeded about 17,000 acres of pinyon-juniper type at an average cost of about $\$ 4.50$ per acre. Forage production was increased an average of approximately 500 lbs. per acre for the 33,000 acres of burned woodland and, according to Schroeder (1964), pinyon and juniper had shown little or no tendency to return on the controlled areas. The average increase in livestock carrying capacity was 45 cow units, grazed yearlong, per 1,000 acres treated. Steers grazed on burned and reseeded areas weighed, on the average, 78 pounds more than steers grazed on adjacent untreated native grass ranges, and brought their owners an average of $\$ 21.75$ more per steer at market time.

The Hualapai Indians wanted to increase livestock production. Burning pinyon and juniper trees, then seeding adapted grasses, provided the answer. However, on public lands where multiple-use goals are a policy requirement, managers may not be able to use fire to solve pinyon-juniper control problems. Nevertheless, the results of controlled burning programs should be studied objectively by those responsible for management of pinyon-juniper rangelands.

No evidence was found to support a common notion that hot, tree-killing pinyon-juniper fires sterilize the soil, making it unfit for grass establishment. In fact, soil samples from "spots covered with ashes where a heavy accumulation of slash and debris had burned" were tested in a greenhouse and reported to have shown "some increased fertility due to burning" (Arnold et al., 1964).
It is hard to reconcile the claims of soil sterilization from fires with reports that pinyon-juniper woodlands are hard to burn; yet both opinions have been offered as partial arguments against prescribed burning in the pinyon-juniper type.

Those who wish to discourage pinyon-juniper burning, lean heavily on the argument that they have trouble getting a fire to carry through a typical woodland. More likely than not they are referring to a carefully controlled burning program attempted when atmospheric and vegetation moisture conditions are such that escape of the fire to adjacent areas would not readily occur. Even those who are experienced and sincere in their efforts to apply fire in pinyon-juniper conversion may have difficulty burning trees when weather conditions are not favorable. For example, Schroeder (1964) reported that a 1955 burn of 700 acres and a 1958 burn of 300 acres, both on the Hualapai Indian Reservation, "were attempts that did not burn the acreage desired. Late wet springs and high moisture content in the shrubs are detrimental to a successful summer burn." Arnold et al. (1964) reported that broadcast burning of live stands of pinyon-juniper at several locations in Arizona was difficult and required "special conditions." They found that, even in stands having over 400 trees per acre "fire will carry only during the hot, dry, windy weather when any burning is hazardous." Dwyer and Pieper (1967) reported that only 24 percent of the juniper trees and 13.5 percent of the pinyons were killed by a wildfire that covered 935 acres of dry grama grassland and open woodland in New Mexico. Humphrey (1962) pointed out that fire in an open pinyon-juniper stand "with cven a scattered understory of perennial grasses" can increase forage production, but grazing can so reduce the potential fuel supply that it is difficult to get fires hot enough to kill a large percentage of the trees.

The Arizona Watershed Program 

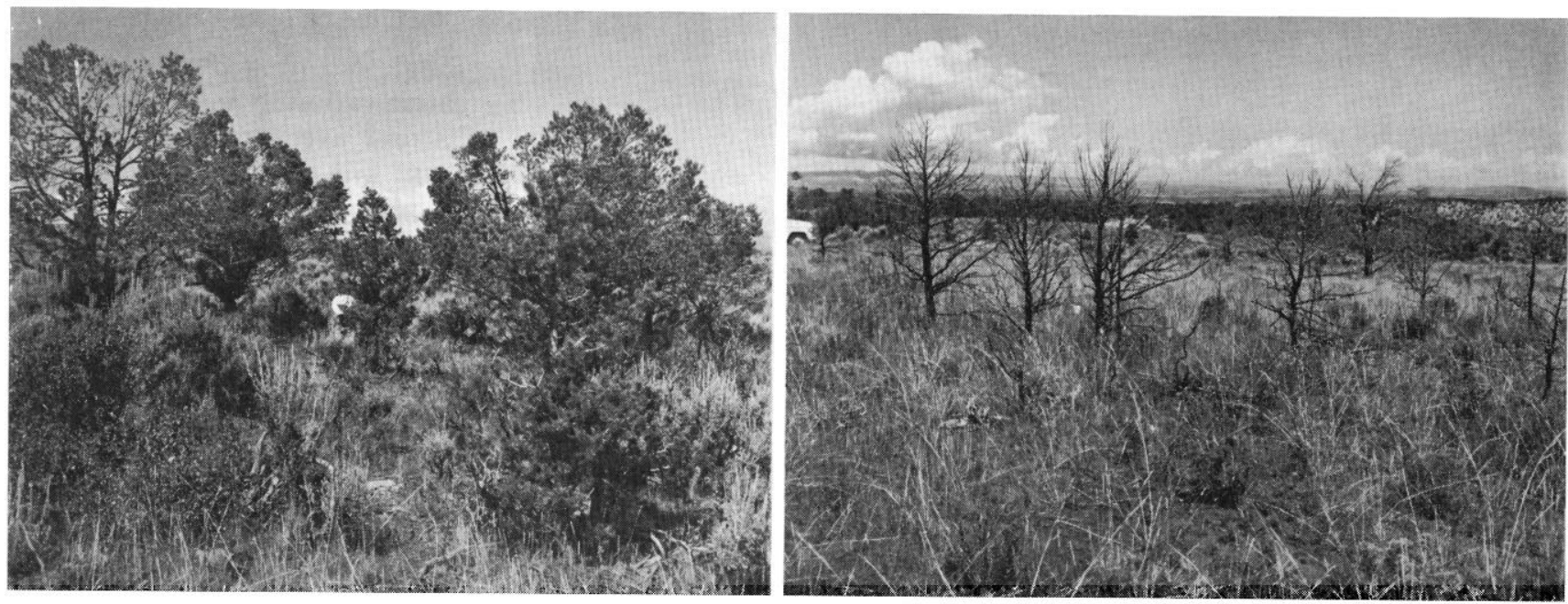

FIG. 4. Pinyon-sagebrush community, northwestern Colorado. Left: Unburned site. In addition to big sagebrush, the understory vegetation included serviceberry, snakeweed, rabbitbrush, needleandthread, and western wheatgrass. A few juniper trees were also present. Right: Adjacent burned area. Serviceberry burned to the ground, but has resprouted vigorously. Establishment of crested wheatgrass, seeded after the fire, is weak compared to aggressive recovery of native grasses.

report of 1956, Recovering Rainfall, stated that "Where fire can be used, it is the most effective method of juniper control," The report cautioned that "Human habitations, intensively used recreational areas, and the like should be rigorously protected." However, it continued, "With these exceptions, in any place where juniper is dense enough to carry a fire, there are no land values that require exclusion of this control agent." The Arizona researchers said "For burning to be effective it must be done when weather conditions will encourage the spread of fire. This usually means burning in June when temperatures are high and humidity is low, and when the risk of escape is greatest. Adequate precautions must be taken to prevent the escape of planned fires and to minimize the damages that might result. When this is done, the calculated risks of a burning program are justified by the potential benefits." The same investigators esti- mated that in the Salt River watershed perhaps less than 10 percent of the pinyon-juniper type could be effectively burned. This somewhat discouraging note agrees with several comments heard by the writer during the present study with regard to the difficulty of burning pinyon-juniper woodlands, but does not square with observations of typical pinyon-juniper stands in Utah, Nevada, Colorado and many parts of Arizona and New Mexico. It is fair, if somewhat idle, to spec-
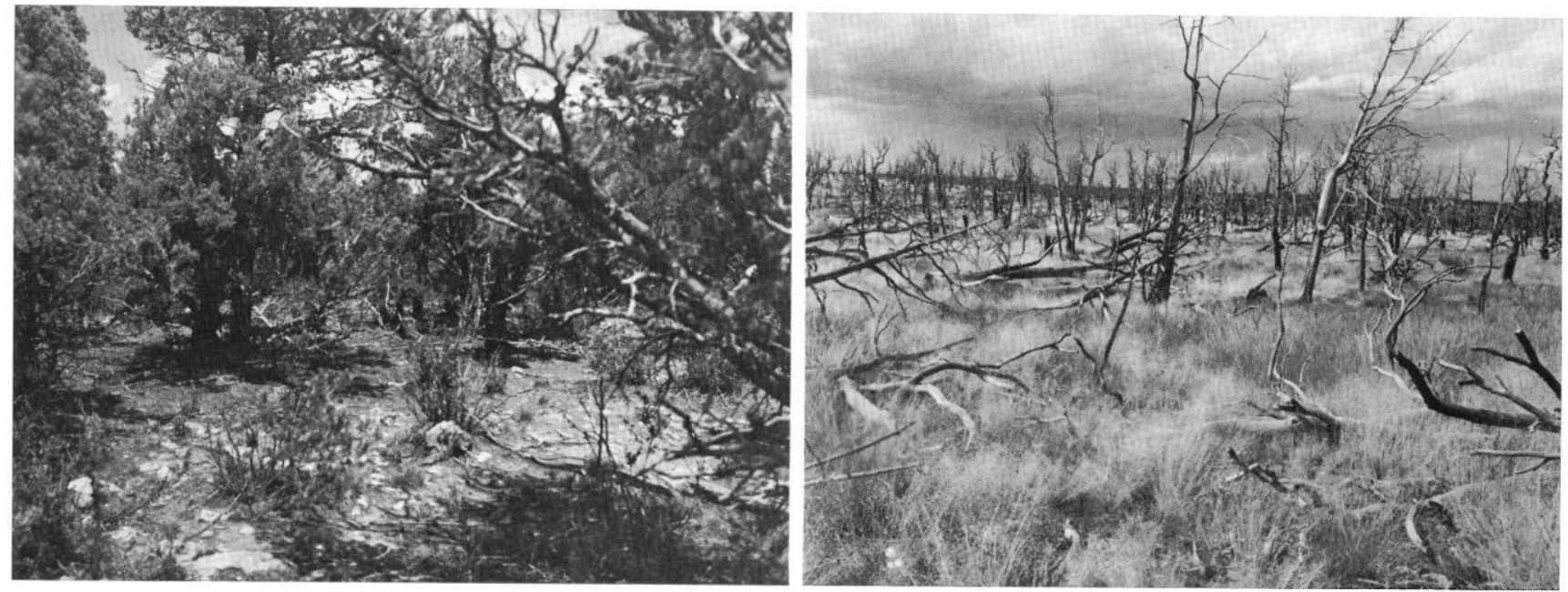

Fig. 5. Pinyon-juniper, northeastern Utah. Left: Untreated stand of mature trees with a sparse understory of mountain mahogany growing on a shallow soil and exposed, fractured limestone. Right: Adjacent burned site. Recovery of native grasses, mainly Indian ricegrass and slender wheatgrass, with no artificial seeding, has increased annual forage production to more than 1,000 pounds of air-dry material per acre. 


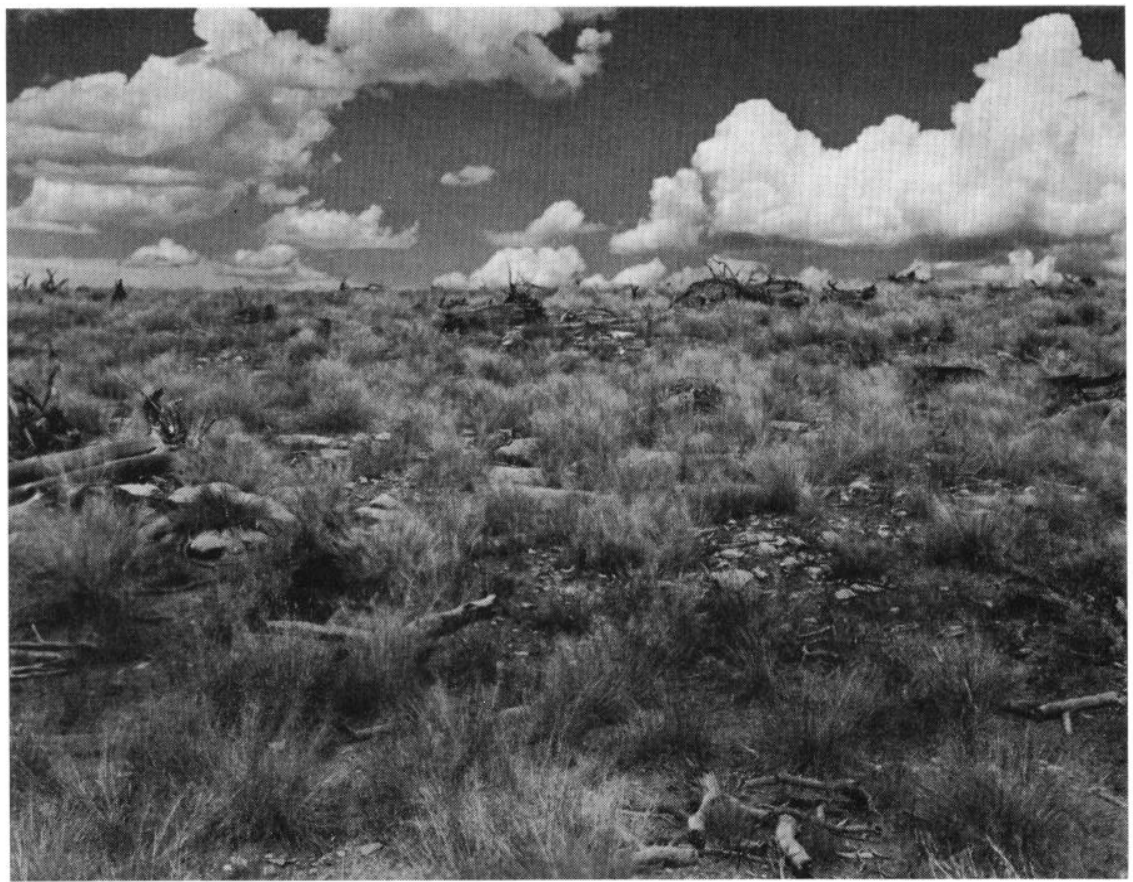

Fig. 6. Successful burn, chained after the fire, northeastern Utah. Site was given the additional treatments of aerial seeding and single chaining to increase forage yields, improve appearance of area, and to facilitate movement of livestock.

ulate that burning could have been used successfully on many of the chaining sites that were examined for the present evaluation. Sites with similar characteristics have had productive burns. Figure 4 illustrates how an accidental burn in northwestern Colorado gave a clean kill on a relatively open stand of pinyon with an understory of sagebrush and some grass. Naturally, where trees are closer together, or where a heavy understory can help carry the fire, the chances of a successful burn will be better. Figure 5 shows the conditions before and after a wildfire had burned a dense stand of pinyon and juniper in Utah. No artificial seeding was applied. Natural recovery of grasses has produced valuable forage and in so doing has made more efficient use of the available water resource. Figure 6 shows the improved appearance obtained by chaining after a successful burn. One chaining site in Utah provided a vivid contrast between the merits of chaining and burning for removing trees and improving range.
An accidental fire cleaned the trash off part of the chained area, providing ideal conditions for aerial seeding of grass. This was done, and now a lush stand of crested wheatgrass grows along side the tangled debris and scant forage on the part of the treatment area that received only double chaining and aerial seeding.

Land administrators will probably give more favorable consideration to conversion of pinyon-juniper woodlands by fire whenever it is demonstrated that burning can be used safely and effectively without detrimental effects to environmental quality. These important aspects of burning are often closely interrelated, and may require new applications of fire that will satisfy all needs. Fire as a tool in pinyon-juniper conversion has sufficient ecologic and economic merit to warrant increased use of present burning techniques now, while further study of new methods may allow more general application of burning in the future.

\section{Summary and Conclusions}

Single chaining projects had the greatest variation in conversion results and averaged only about 40 percent kill on trees, lowest for all methods examined. Double chaining was less variable, but also was less than twice as effective in killing trees. Windrowing and burning gave consistently high tree kills of 95 percent or better, and offer the best chances for pinyon-juniper conversion success.

Controlled burning should be the primary pinyon-juniper conversion technique where vegetation is dense enough to carry an effective fire. Range managers and policy-makers should develop and maintain a balanced perspective on fire as a natural and beneficial instrument in vegetation change.

The windrowing technique is an excellent mechanical method for complete conversion, but should be used only where fire is legitimately prohibitive and where topography and soil properties allow intensive “grass farming” operations.

Single or double chaining should be used only where other means are precluded for good reason, or where only partial tree control is acceptable, such as in some wildlife habitat improvement projects. In neither case would conversion of woodland to grassland be an expected result. Chaining should be most effective where at least 50 percent of the trees are over 10 feet in height.

Any proposed conversion project should receive an appropriate economic evaluation of its benefits versus its costs (Eckstein, 1958; Gardner, 1962; Kearl and Brannan, 1967; LeBaron, 1965; Lloyd and Cook, 1960). This applies with special emphasis to the intensive windrowing method.

\section{Literature Cited}

Arizona Watershed Program. 1956.

Recovering rainfall. Part I, $33 \mathrm{p}$.

Arnold, J. F. 1959. Effects of juniper invasion on forage production and erosion. Your range-its manage- 
ment. Ariz. Agr. Ext. Serv. Spec. Rep. 2:17-18.

Arnold, J. F., ANd W. L. Schroeder. 1955. Juniper control increases forage production on the Fort Apache Indian Reservation. Rocky Mountain Forest and Range Exp. Sta., Forest Serv. Paper 18. $35 \mathrm{p}$.

Arnold, J. F., D. A. Jameson, ANd E. H. REID. 1964. The pinyon-juniper type of Arizona: effects of grazing, fire, and tree control. U.S. Dep. Agr. Prod. Research Rep. 84. 28 p.

CaIN, D. R. 1969. Some suggested principles and procedures for successful range restoration. Ely Chain. Proc. Wildl. Habitat Manage. Proc. (mimeogr.) Bur. Land Manage. Ely, Nevada.

Chilson, E. W. 1964. Increasing livestock production through juniper control. Proc. 8th Annu. Ariz. Watershed Symp.:28-30.

Choate, G. A. 1966. New Mexico's forest resource. Forest Serv. Resource Bull. INT-5. $58 \mathrm{p}$.

Соок, C. W. 1966. Development and use of foothill ranges in Utah. Utah Agr. Exp. Sta. Bull. 461.47 p.

Cotner, M. L. 1963. Controlling pinyon-juniper on southwestern rangelands. Ariz. Agr. Exp. Sta. Rept. $210.28 \mathrm{p}$.

Dortignac, E. J. 1960. Water yield from pinyon-juniper woodland. Water Yield in Relation to Environment in the Southwestern United States. Amer. Ass. Adv. Sci. Symp. Sul Ross State College, Alpine, Texas.

Dwyer, D. D., ANd R. D. Pieper. 1967. Fire effects on blue grama-pinyonjuniper rangeland in New Mexico. J. Range Manage. 20:359-362.
ECKSTEIN, OTto. 1958. Water resource development, the economics of project evaluation. Cambridge, Mass., Harvard Univ. Press. 300 p.

GARDNER, B. D. 1962. Rates of return to improvement practices on private and public ranges. Land Econ. 38:43-50.

Humphrey, R. R. $1962 . \quad$ Range ecology. The Ronald Press, New York. $234 \mathrm{p}$.

Hull, A. C., C. W. Doran, C. H. WASSER, AND D. F. HeRVEY. 1952. Reseeding sagebrush lands of western Colorado. Colo. Agr. Exp. Sta. Bull. 413-A. 27 p.

Johnsen, 'T. N., Jr. $1962 . \quad$ One-seed juniper invasion of northern Arizona grasslands. Ecol. Monog. 32: 187-207.

Kearl, W. G., and M. Brannan. 1967. Economics of mechanical control of sagebrush in Wyoming. Wyo. Agr. Exp. Sta. Sci. Monog. 5. 35 p.

LeBaron, Allen. 1965. Cost-benefit calculations in American water resource policy literature. Proc. Utah Acad. Sci. Arts and Letters 42. Part 1 .

Leopold, Aldo. 1924. Grass, Brush, timber and fire in southern Arizona. J. Forestry 22:2-10.

Lloyd, R. D., ANd C. W. Cook. 1960. Sccding Utah's ranges-an economic guide. Utah Agr. Exp. Sta. Bull. 423. 19 p.

Mason, Lamar. 1963. Using historical records to determine climax vegetation. J. Soil and Water Conserv. 18:190-194.

Nichol, A. A. 1943. The natural vegetation of Arizona. Ariz. Agr. Exp. Sta. Tech. Bull. 68. 222 p.

PARker, K. W. 1945. Juniper comes to the grasslands. Why it invades southwestern grassland-suggestions on control. Amer. Cattle Producer 27:12-14, 30-32.

Pearson, G. A. 1931. Forest types in the southwest as determined by climate and soil. U.S. Dep. Agr. Tech. Bull. 247. $144 \mathrm{p}$.

Plummer, A. P., D. R. Christensen, and S. B. Monsen. 1968. Restoring big-game range in Utah. Utah Div. Fish and Game Pub. 68:3. 183 p.

Preston, R. J., JR. 1940. Rocky Mountain trees. The Iowa State College Press, Ames, Iowa. 285 p.

Reynolds, H. G. 1964. Elk and deer habitat use of pinyon-juniper woodland in southern New Mexico. $\mathbf{N}$. Amer. Wildl. and Nat. Resources Conf. Trans. 29:438-444.

Schroeder, W. L. 1964. Hualapai brush control report. Bur. Indian Affairs. U.S. Dep. Interior Mimeogr. Rep. 7.

Shown, L. M., R. F. Miller, ANd F. A. Branson. 1969. Sagebrush conversion to grassland as affected by precipitation, soil, and cultural practices. J. Range Manage. 22:303-311.

Stoddart, L. A., AND A. D. SMith. 1955. Range management. McGrawHill Book Co., Inc. 431 p.

U.S. DeP. OF Agr. 1958. Timber resources for America's future. Forest Serv. Resource Rep. 14.

U.S. Der. OF AGR. 1963. Rocky Mountain Forest and Range Exp. Sta. Annu. Rep.

Wilson, A. M., J. R. Nelson, and C. J. GOEBEL. 1970. Effects of environment on the metabolism and germination of crested wheatgrass seeds. J. Range Manage. 23:283-288.

WoOdBury, A. M. 1947. Distribution of pigmy conifers in Utah and northeastern Arizona. Ecology 28:113-126.

\section{Plaque for A. W. Sampson}

The 60th Anniversary of the Great Basin Experimental Range will be celebrated in conjunction with SRM's 1972 summer meeting. As a part of the planned events, a plaque will be dedicated to Arthur W. Sampson, who was the first director of the Experimental Range (originally designated Utah Experiment Station). Many of Professor Sampson's range management concepts were developed through his research at this station.

The Utah Section, SRM, is serving as the recipient for funds for the proposed plaque. Contributions in any amount are being solicited and may be sent to A. T. Fillingim, Secretary-Treasurer, Utah Section, SRM, 850 North 10th East, Price, Utah 84501. 